\title{
フラットプレート構造の地震時荷重抵抗機構モデルに関する研究 MODEL FOR THE STIFFNESS AND THE STRENGTH OF FLAT-PLATE STRUCTURES
}

\author{
太田義弘*，川合＼cjkstart拓**，太田博章*** \\ Yoshihiro OHTA, Taku KAWAI and Hiroaki OHTA
}

\begin{abstract}
This paper describes a model for the stiffness and the strength of flat-plate structures under the lateral loads. The following things are shown.

1. The predicted shear force at column - story drift envelopes by this model agree with the measured ones.

2. The predicted distributions for stresses of the reinforced steels at the critical section of slab by this model agree with the measured ones.

3. After the reinforced steels at the critical section of slab are yielded, the predicted and measured values for the reinforced steels stresses in the anchor aren't in good agreement. This is investigated in future.
\end{abstract}

Keywords : flat-plate structure, stiffness, strength, macro model, flexural element, torsional element フラットプレート構造, 剛性, 而力, マクロモデル, 曲げ要素, ねじり要素

\section{1. はじめに}

地球環境を守ることは, 現在から未来に続く人類にとって最も重 要かつ最優先される課題である。建築の分野においても地球環境を 守るための様々な試みがなされ, 建物の長寿命化に関する技術開発 もその一つの動きと考えられる。建物の長寿命化を図るためには, 構造体の耐久性を向上させることに加えて, 設備の更新やライフス タイルの変化などに柔軟に対応可能であるような建物にすることが 不可欠であると考えられる。

このような社会的ニーズに対応可能な構造, 仕上げ・設備の更新 にも容易に対応可能な構造として, 床版と柱のみからなるフラット スラブ構造およびフラットプレート構造がある。図 1 に示すように フラットスラブ構造は柱頭または柱頭と支板のある構造形式を示し, 柱頭および支板の無いものはフラットプレート構造の名称で区別さ れる。フラットスラブ構造は 20 世紀の初頭にターナー, マイヤー ルによって研究がはじめられ, ヨーロッパやアメリカの地震の少な い地域を中心に広く用いられている。しかし, 柱周りのせん断破壞 （パンチング破壊）による脆性的な壊れ方をする可能性が高いこと や地震力のような水平力に対して剛性が低いといった欠点により, 地震の多い日本では建物外周の大部分に耐震壁を配置することが可 能な低層の倉庫や地下の駐車場等で用いられてきた。しかし，阪神
淡路大震災以降における免震・制震技術の進歩や設計法の性能評価 型への移行により，住宅を中心にフラットプレート構造を採用する 建物が近年増加している。1 1 ,2) フラットプレート構造を広く建物に適 用していく上では, フラットプレート構造の構造特性, 特に以下に 示す地震時を想定した水平荷重を受けた場合の構造特性を明らかに する必要がある。

・柱周りのスラブにおけるパンチング破壊耐力

・水平荷重に対する剛性および耐力

柱周りのスラブのパンチング破壊に関しては，狩野らによる研究 3) 6)に基づくパンチング破壊耐力の算定方法および設計式が鉄筋コ ンクリート構造計算規準 7によめられている。一方, 水平力に対 する剛性および耐力に関しては定量的かつ汎用性のある評価方法が ほとんど示されていない。鉄筋コンクリート構造計算規準では，狩 野らによる弾性理論に基づく応力分布に対して曲げに関する検討を 行うことが記述されている程度に留まり, 終局時の耐力やスラブの 非線形性を考慮した水平荷重と変形の評価方法に関しては示されて いない。終局時の耐力や非線形性を考慮した水平荷重と変形の評価 方法に関しては津田らによる研究 ${ }^{8 \sim 12)}$ があるが, スラブの幅が限定 された実験に基づいており，適用範囲は非常に限定されている。ま た，海外においては，Durrani らがスラブの非線形性を考慮した

\footnotetext{
* 竹中工務店技術本部 副部長 ·工修

** 竹中工務店設計部 グループリーダー・工修

**** 竹中工務店設計部 マネージャー・工修
}

Vice Senior Manager, Technology Department, Takenaka Corporation, M. Eng. Group Leader, Building Design Department, Takenaka Corporation, M. Eng. Manager, Building Design Department, Takenaka Corporation, M. Eng. 
Equivalnet Beam Width Model13),14)を提案しているが, 水平剛性に 寄与するスラブの有効幅は既往の実験結果による実験式であるため, 実際に水平剛性に寄与するスラブ範囲を示寸ものではなく, スラブ に配置された各位置での鉄筋の効果を定量的に示すものではない。

本研究の目的は, フラットプレート構造の地震時を想定した水平 荷重を受けた場合の耐力および剛性の算定に関して，スラブの非線 形性を考慮した定量的かつ汎用性がある方法, 柱とスラブの応力伝 達を適切に表現可能なマクロモデルによる算定方法を提案するもの である。

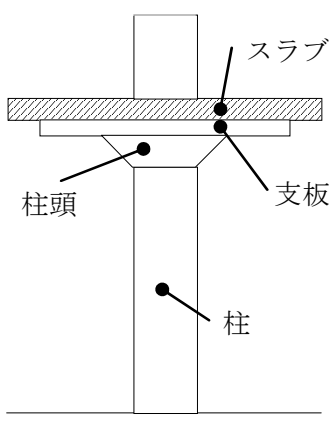

フラットスラブ構造

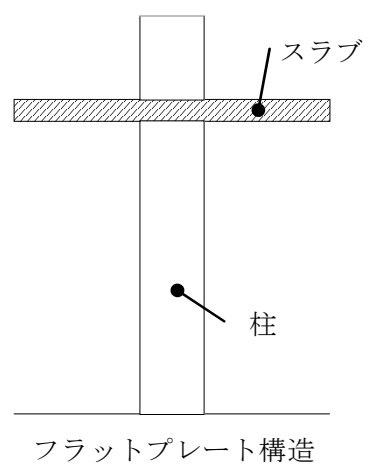

図 1 フラットスラブおよびフラットプレート構造

\section{2. マクロモデルによる算定方法}

\section{(1) 基本概念}

フラットプレート架構におけるスラブと柱の力の伝達機構を図 2 に示す。フラットプレート架構に水平荷重が加わる場合, 柱からの 断面力は（a）柱前後面のスラブの曲げ（b）柱側面のスラブのねじ りによって，柱からスラブに伝達される。Hawkins らは，この柱か らスラブへの力の伝達機構を表現しながら, 柱からスラブに伝達さ れる力と柱近傍のスラブの変形の関係を示す Stub Beam Model を 提案した ${ }^{15)}$ 。Stub Beam Model は, 図 3 に示すように柱近傍のス ラブを曲げ要素（図 3 中の F1，F2）とねじり要素（図 3 中の $\mathrm{T} 1$, T2）に分割して，曲げ要素およびねじり要素のそれぞれの断面力と 変形の関係と曲げ要素とねじり要素の変形の適合性によって，フラ ツトプレートの水平荷重と柱近傍のスラブの変形の関係を表わすも のである。筆者らは, 各要素の断面力と変形の関係と変形の適合性 から構成されるこの Stub Beam Model の考え方を踏襲しながら， Stub Beam Model の欠点である（a）Stub Beam Model での水平 荷重とスラブの変形の関係が柱からスラブに伝達される曲げモーメ ントと, 柱とスラブ近傍の接合部の回転角の関係に限られているこ と, (b) Stub Beam Model ではねじり要素の長さは変形が増加し ても一定であり, 実験において確認される架構全体の水平変形の増 加に伴う柱側面のスラブにおけるねじり変形の広がりの進展, 具体 的にはスラブひび割れの進展とスラブ主筋の応力伝達部分の広がり を示していないことに対して，改良を加えたマクロモデルを提案す る。

図 4 に内柱タイプのフラットプレート架構における水平荷重を受 けた場合の変形状態を示す 16$)$ 。スラブの水平荷重方向を材軸とした 時の回転角は, 水平荷重と直交する方向では一定ではなく, 柱中心 では最も大きく，柱中心から離れるにしたがって小さくなる。

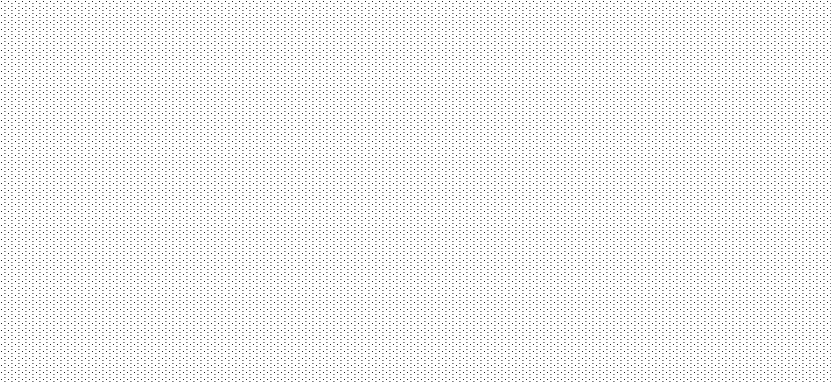

図 2 フラットプレート架構におけるスラブと柱のカの伝達機構

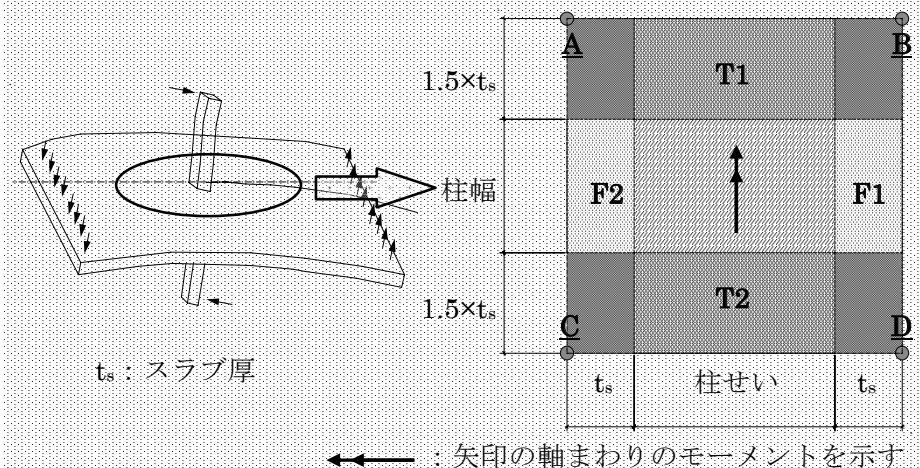

図 3 Hawkins らによる Stub Beam Model (内柱タイプ) ${ }^{15)}$

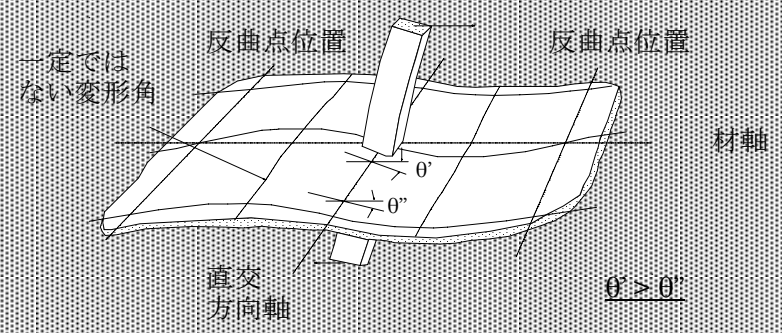

図 4 フラットプレート架構の変形状態 ${ }^{16)}$

このような変形状態を想定した内柱タイプのフラットプレート部 分架構を図 5 に示す。この部分架構は，水平荷重方向に対してはス ラブの反曲点位置まで, 水平荷重と直交する方向に対してはスラブ の回転角が 0 となる位置までを切り出したものとする。提案するマ クロモデルは, 図 5 に示すようにスラブを, 曲げ要素, ねじり要素, 応力伝達要素および先端要素に分割して, 柱とスラブ各要素間およ びフラットプレート架構モデル全体における力の釣り合いと柱とス ラブの接合部近傍における曲げ要素とねじり要素の変形の適合性か らフラットプレート構造の水平荷重を受けた場合の耐力および剛性 の関係を示すものである。

曲げ要素に関しては，曲げ要素の幅は Hawkins らによる Stub Beam Model では柱幅であるのに対して，提案するマクロモデルで は柱幅に曲げ要素長さを加えた長さとし, 曲げ要素の先端からスラ ブのせん断力と曲げモーメントが柱に伝達されるものとする。 
ねじり要素に関しては, 水平荷重と平行な長さは, Hawkins らに よるStub Beam Model では柱せいであるのに対して, 提案するマ クロモデルでは図 5 に示すように, 柱せい $\mathrm{C}_{1}$ にスラブ厚さ $\mathrm{t}_{\mathrm{s}}$ に等 しい長さの 2 倍を加えた長さとしている。また, 水平荷重と直交す る長さは Hawkins らによる Stub Beam Model ではスラブ厚さの 1.5 倍の長さであるのに対して, 提案するマクロモデルでは力の釣 り合いと柱とスラブの接合部近傍における曲げ要素とねじり要素の 変形の適合性から長さが変動するものとする。

応力伝達要素は, 曲げ要素から伝達されるスラブのせん断力と曲 げモーメント, ねじり要素から伝達されるスラブの曲げモーメント (ねじりモーメント) を柱に伝達する。市ノ瀬らの研究 17),18)におい ては，柱側面からもスラブのせん断力と曲げモーメントが柱に伝達 するとしているが，提案するマクロモデルでは Hawkins らによる Stub Beam Model および狩野らによる研究 3) 6)に基づく断面力の 伝達の考え方に準拠して曲げ要素の曲げ有効幅の部分で伝達される スラブのせん断力と曲げモーメントは柱前面および後面から伝達さ れるものとする。また, 応力伝達要素および曲げ要素とねじり要素 の先端以外の接している部分における変形の適合性は成立しないも のとする。

先端要素は, 曲げ要素およびねじり要素から伝達されるスラブの せん断力と曲げモーメントを伝達する弾性要素とする。

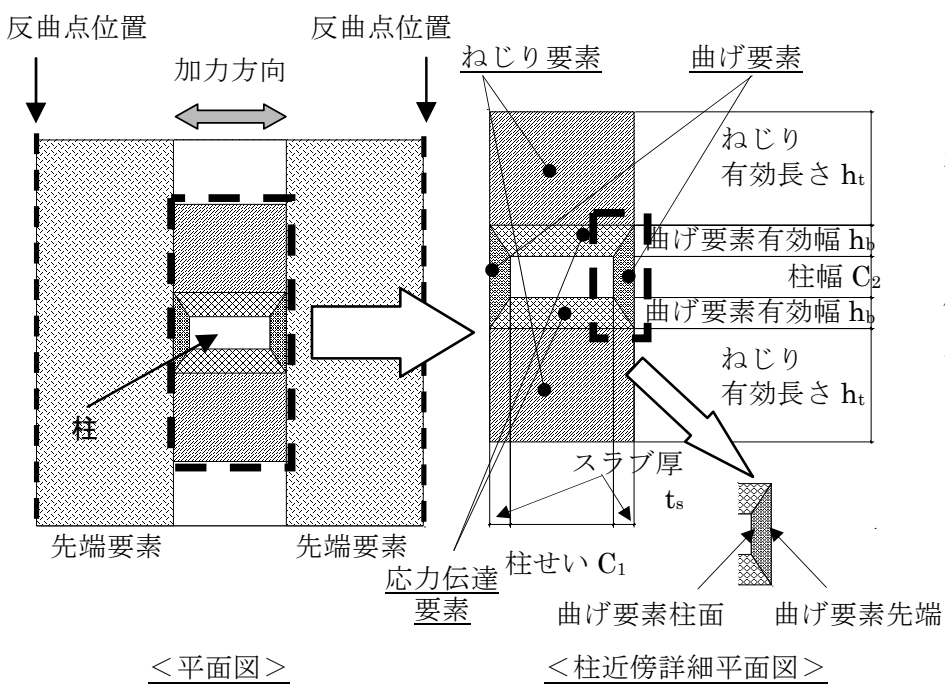

\section{図 5 提案するマクロモデルの概要}

\section{(2) マクロモデルによる解析}

フラットプレート部分架構におけるマクロモデルによる解析フロ 一を図 6 に示す。以下に概要を示す。

1）曲げ要素の断面解析

曲げ要素は, 梁幅を柱幅 $\mathrm{C}_{2}$ と曲げ有効幅 $\mathrm{h}_{\mathrm{b}}$ の和 $\mathrm{C}_{2}+2 \mathrm{~h}_{\mathrm{b}}$, 梁せ いをスラブ厚 $\mathrm{t}_{\mathrm{s}}$, 梁主筋を梁幅内のスラブ主筋, 材軸方向の長さを スラブ厚 $\mathrm{t}_{\mathrm{s}}$ とする梁部材として考える。

断面解析は曲げ要素柱面における圧縮側コンクリートの縁ひずみ を設定し, それに対して平面保持が成立するとしてファイバー法に より，材軸方向の力の釣り合いから曲げ要素柱面における曲率，コ ンクリートの応力およびひずみ分布, 主筋の応力およびひずみ, 曲
げモーメントを算出する。

ファイバー法におけるコンクリートの応力とひずみの関係式は NewRC 式 ${ }^{19)}$, 主筋の応力とひずみの関係式はひずみ硬化を考慮し たおよび島ら 20)による式を用いる。

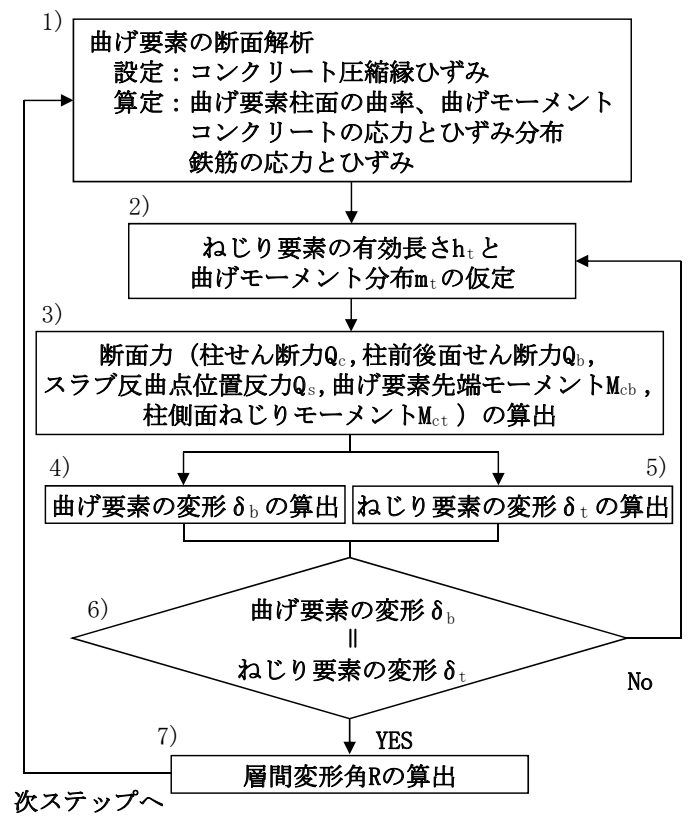

図 6 マクロモデルによる解析フロー

2) 衫じり要素のねじり有効長さ $h_{t}$ と曲げモーメント分布 $\mathrm{m}_{\mathrm{t}}$ の仮定 ねじり要素の有効長さ $\mathrm{h}_{\mathrm{t}}$ の設定方法と曲げ要素およびねじり要 素にかけての単位長さ当りの曲げモーメント分布を図 7 に示す。単 位長さ当りの曲げモーメントは曲げ要素幅では一定として, ねじり 有効長さの先端では 0 となるように線形的に分布するものとする。 ただし, ねじり要素における単位長さ当りの曲げモーメントは, 曲 げモーメント想定位置での曲げ降伏モーメント以下となるようにす る。

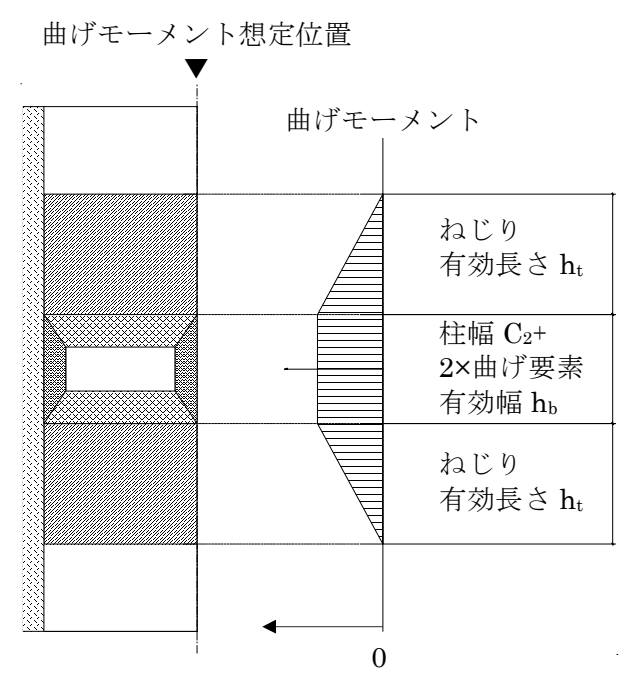

図 7 ねじり要素の有効長さと曲げモーメント分布 
3）各断面力の算出

スラブにおける曲げ要素, ねじり要素, 応力伝達要素および先端 要素, 柱部材における各断面力の釣合いを図 8 に示す。以下に各要 素における断面力の釣合式を示す。

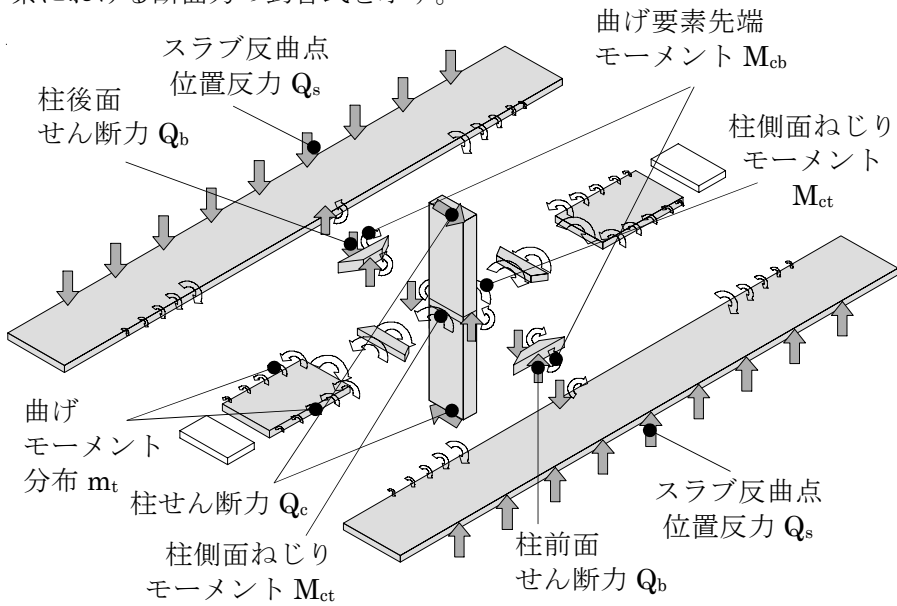

図 8 断面力の釣合い

・柱部材の柱中心位置での曲げモーメントの釣合い

$$
2 \cdot \mathrm{Q}_{\mathrm{c}} \cdot \mathrm{L}_{\mathrm{c}}=\mathrm{Q}_{\mathrm{b}} \cdot\left(\mathrm{C}_{1}+2 \cdot \mathrm{t}_{\mathrm{s}}\right)+2 \cdot \mathrm{M}_{\mathrm{cb}}+2 \cdot \mathrm{M}_{\mathrm{ct}}
$$

・スラブの先端要素の反曲点位置での曲げモーメントの釣合い

$$
\mathrm{Q}_{\mathrm{b}} \cdot\left(\mathrm{L}_{\mathrm{s}}-0.5 \cdot \mathrm{C}_{1}-\mathrm{t}_{\mathrm{s}}\right)=\mathrm{M}_{\mathrm{cb}}+2 \cdot \int \mathrm{m}_{\mathrm{t}}
$$

・スラブの先端要素のせん断力の釣合い

$\mathrm{Q}_{\mathrm{s}}=\mathrm{Q}_{\mathrm{b}}$

・モデル全体の柱中心位置での曲げモーメントの釣合い

$2 \cdot \mathrm{Q}_{\mathrm{c}} \cdot \mathrm{L}_{\mathrm{c}}=2 \cdot \mathrm{Q}_{\mathrm{s}} \cdot \mathrm{L}_{\mathrm{s}}$

・ねじり要素での曲げモーメントの釣合い

$\mathrm{M}_{\mathrm{ct}}=2 \cdot \int \mathrm{m}_{\mathrm{t}}$

ここで,

$\mathrm{Q}_{\mathrm{c}}$ : 柱せん断力

$\mathrm{Q}_{\mathrm{b}}$ : 柱前面および後面のせん断力

$\mathrm{Q}_{\mathrm{s}}$ : スラブ反曲点位置反力

$\left.\int \mathrm{m}_{\mathrm{t}}: 2\right)$ で仮定したねじり要素の曲げモーメント分布 $\mathrm{m}_{\mathrm{t}}$ に 対してねじり有効長さ $\mathrm{h}_{\mathrm{t}}$ で積分した值

$\mathrm{M}_{\mathrm{cb}}$ : 曲げ要素先端での曲げモーメント

$\mathrm{L}_{\mathrm{c}}$ ：スラブ中心位置から柱支持位置までの長さ

$\mathrm{L}_{\mathrm{s}} \quad$ : 柱中心からスラブ反曲点位置までの長さ

$\mathrm{M}_{\mathrm{ct}}$ : 柱側面ねじりモーメント

$\mathrm{t}_{\mathrm{s}}$ : スラブ厚さ

$\mathrm{C}_{1}$ : 柱せい

4）曲げ要素の変形 $\delta_{b}$ の算出

曲げ要素の変形 $\delta_{\mathrm{b}}$ は, 曲げ要素柱面と曲げ要素先端の相対変位を 示しており, 式（6）に示すように 3 つの変形成分の和からなるも のとする。

$\delta_{\mathrm{b}}=\delta_{\mathrm{bb}}+\delta_{\mathrm{bs}}+\delta_{\mathrm{bslip}}$

ここで,

$\delta_{\mathrm{bb}} \quad$ : 曲げ変形

$\delta_{\mathrm{bs}}$ : 世九断変形 $\delta_{\text {bslip }}$ :曲げ要素柱面におけるスラブ主筋の抜け出し(すべり) による変形

曲げ変形 $\delta_{b b}$ は, 図 9 に示す曲げ要素の材軸長方向の曲率分布に 対して材軸長にわたって積分した值とする。せん断変形 $\delta_{\mathrm{bs}}$ は，柱 前面（後面）せん断力と曲げ要素のせん断弾性剛性より算出する。 ここで, 曲げ変形 $\delta_{\mathrm{bb}}$ 及びせん断変形 $\delta_{\mathrm{bs}}$ の算定時における曲げ要素 の幅は柱幅 $\mathrm{C}_{2}$ と曲げ有効幅 $\mathrm{h}_{\mathrm{b}}$ の和 $\mathrm{C}_{2}+2 \mathrm{~h}_{\mathrm{b}}$ であり，材軸長にわた って一定である。

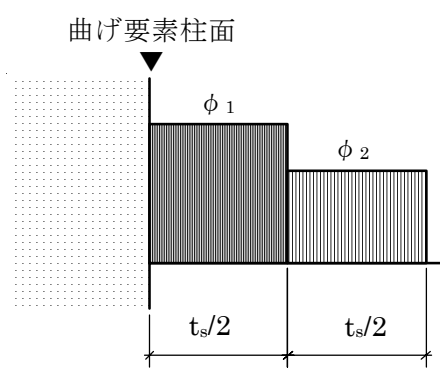

$\phi_{1}:\lceil 1)$ 曲げ要素の断面解析 において算出した曲率 $\phi_{2}:\lceil 3)$ 各断面力の算出」に おいてした算出された曲け 先端要素モーメント $\mathrm{M}_{\mathrm{cb}}$ に 対してファイバー法により 算出した曲率

抜け出しによる変形 $\delta_{\mathrm{bslip}}$ に関しては, 図 10 にスラブ主筋の抜け 出しによる変形の概念図，算定式を式（7）に示す。スラブ主筋の 抜け出しによる変形（すべり変形）の算出にあたっては，1）曲げ 要素の断面解析で算出した中立軸位置高さ, 鉄筋のひずみと島らに よる鉄筋の付着応力-すべり量-ひずみ関係 20),21)より算出する。

$$
\delta_{\text {bslip }}=\mathrm{S} \cdot \mathrm{t}_{\mathrm{s}} /\left(\mathrm{d}-\mathrm{X}_{\mathrm{n}}\right)
$$

$$
\text { ここで, }
$$

S : 曲げ要素柱面からの主筋の抜け出し量

$\mathrm{d}$ : スラブの引張側主筋の有効せい

$\mathrm{X}_{\mathrm{n}}$ ：中立軸位置高さ

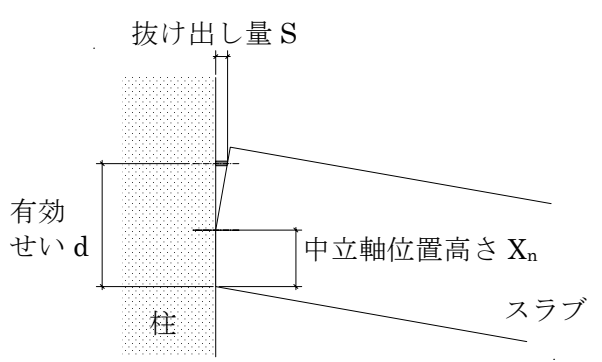

\section{図 10 スラブ主筋の曲げ要素柱面からの抜け出しによる変形}

主筋の抜け出し量 $\mathrm{S}$ の算出方法を以下に示す。

曲げ要素柱面を原点として，スラブ主筋の材軸にそった端部から $\mathrm{x}$ までの距離からのすべり量 $\mathrm{D}_{\text {slip }}$ は，式（8）による。

$\mathrm{D}_{\text {slip }}=\int \varepsilon d \mathrm{x}$

ここで,

$\varepsilon \quad:$ スラブ主筋のひずみ

また，鉄筋にそった任意の点における鉄筋の付着応力 $て$ は，鉄筋 の応力の傾き $\mathrm{d} \sigma / \mathrm{dx}$ から式（9）のように表わすことができる。

$$
\tau=\mathrm{D} / 4 \cdot \mathrm{d} \sigma / \mathrm{dx}
$$

島らは, 異形鉄筋の付着実験から鉄筋の付着応力 $\tau$, すべり量 $\mathrm{D}_{\mathrm{slip}}$, スラブ主筋のひずみとの関係式を示した。 


$$
\begin{aligned}
& \tau / \mathrm{f}_{\mathrm{c}}=0.73 \cdot(\ln (1+5 \cdot \mathrm{s}))^{3} /\left(1+\varepsilon \cdot 10^{5}\right) \\
& \text { ここで } \\
& \mathrm{s}=1000 \cdot \mathrm{D}_{\mathrm{slip}} / \mathrm{D} \\
& \mathrm{f}_{\mathrm{c}}: \text { コンクリート強度 } \\
& \mathrm{D}: \text { 鉄筋径 }
\end{aligned}
$$

曲げ要素柱面からの抜け出し量は, 式 (8), (9), (10) より算出 したすべり量 $\mathrm{D}_{\text {slip }}$ をスラブ側と柱側からによるものと地震時にお ける繰り返し載荷の影響を受けるものとして，式（11）とした。

$$
\mathrm{S}=2 \cdot \mathrm{D}_{\text {slip }}
$$

以上の曲げ要素の変形 $\delta \mathrm{b}$ 算定時には, 隣接する応力伝達要素, 先端要素およびねじり要素の影響は考慮していない。

\section{5）ねじり要素の変形 $\delta_{\mathrm{t}}$ の算出}

ねじり要素におけるねじりモーメントとねじり曲率の関係を図 1 1 に示す。ここで, ねじり曲率は単位長さあたりの㸚じり回転角と する。㸚じりモーメントと㸚じり曲率の関係はバイリニアー型とし， Hawkins らによるStub Beam Model に用いている式を参考に 15), それぞれの值は式（12）～（19）によって算出する。

<ねじりひび割れ時 $\left(\varphi_{\mathrm{cr}}, \mathrm{T}_{\mathrm{cr}}\right)>$

ねじりひび割れモーメント $\mathrm{T}_{\mathrm{cr}}$ は，式（12）により算出する。

$$
\begin{aligned}
& \mathrm{T}_{\mathrm{cr}}=\left(\mathrm{t}_{\mathrm{S}}{ }^{2}+6452\right) \mathrm{C}_{1} \cdot \mathrm{f}_{\mathrm{c}} \\
& \text { ここで }
\end{aligned}
$$

$\mathrm{T}_{\mathrm{cr}}$ ：ねじりひび割れモーメント $(\mathrm{Nmm})$

ねじりひび割れ時のねじり曲率 $\varphi_{\mathrm{cr}}$ は式（13）により算出する。

$$
\begin{aligned}
& \varphi_{\mathrm{cr}}=\mathrm{T}_{\mathrm{cr}} /\left(\mathrm{G}_{\mathrm{c}} \cdot \mathrm{J}_{\mathrm{c}}\right) \\
& \text { ここで }
\end{aligned}
$$

$\mathrm{G}_{\mathrm{c}} \quad$ : コンクリートのせん断弾性剛性 $\left(\mathrm{N} / \mathrm{mm}^{2}\right)$

$\mathrm{J}_{\mathrm{c}}$ : ねじり剛性 $\left(\mathrm{mm}^{4}\right)<$ 式（14）による $>$

$$
\mathrm{J}_{\mathrm{c}}=1 / 3 \cdot\left(1-0.63 \cdot \mathrm{t}_{\mathrm{s}} / \mathrm{C}_{1}\right) \cdot \mathrm{t}_{\mathrm{S}}{ }^{3} \cdot \mathrm{C}_{1}
$$

<ねじり降伏時 $\left(\phi \mathrm{y}, \mathrm{T}_{\mathrm{y}}\right)>$

永じり降伏モーメント $\mathrm{T}_{\mathrm{y}}$ は式（15）により算出する。

$$
\begin{aligned}
\mathrm{T}_{\mathrm{y}} & =0.21 \cdot \mathrm{f}_{\mathrm{c}}{ }^{0.5} \cdot\left(\mathrm{C}_{1}+2 \cdot \mathrm{t}_{\mathrm{s}}\right) \cdot \mathrm{t}_{\mathrm{S}}{ }^{2} \\
& +1.5 \cdot\left(\mathrm{C}_{1}+2 \cdot \mathrm{t}_{\mathrm{s}}\right) \cdot\left(\mathrm{d}-\mathrm{d}{ }^{\prime}\right) \cdot \mathrm{a}_{\mathrm{sh}} \cdot \mathrm{f}_{\mathrm{y}} / \mathrm{p}
\end{aligned}
$$
ここで

$$
\begin{aligned}
\mathrm{T}_{\mathrm{y}} & : \text { 小じり降伏モーメント }(\mathrm{Nmm}) \\
\mathrm{d}^{\prime} \quad: \text { スラブ圧縮縁からスラブ圧縮側 } & \text { ス離 }(\mathrm{mm}) \\
& \text { 路 } \\
\mathrm{a}_{\mathrm{sh}} & : \text { スラブ主筋の断面積 }\left(\mathrm{mm}^{2}\right) \\
\mathrm{f}_{\mathrm{y}} & : \text { スラブ主筋の降伏強度 }\left(\mathrm{N} / \mathrm{mm}^{2}\right) \\
\mathrm{p} & : \text { スラブ主筋のピッチ }(\mathrm{mm})
\end{aligned}
$$$$
d^{\prime} \text { : スラブ圧縮縁からスラブ圧縮側主筋の重心位置までの }
$$

ねじり降伏時のねじり曲率 $\varphi_{\mathrm{y}}$ は式（16）により算出する。

$$
\varphi_{\mathrm{y}}=\mathrm{T}_{\mathrm{y}} /(\mathrm{GJ})_{\mathrm{cr}}
$$

ここで

$(\mathrm{GJ})_{\mathrm{cr}}$ ：ねじり降伏時の割線ねじり剛性 $\left(\mathrm{Nmm}^{2}\right)$

$$
\begin{aligned}
& <\text { 式（17）による } \\
& (\mathrm{GJ})_{\mathrm{cr}}=\frac{\mathrm{E}_{\mathrm{s}} \cdot\left(\mathrm{C}_{1}+2 \mathrm{t}_{\mathrm{s}}\right)^{3} \cdot \mathrm{t}_{\mathrm{o}}{ }^{3} \cdot \rho_{\mathrm{h}} \cdot \rho_{1}}{\left(\mathrm{C}_{1}+2 \mathrm{t}_{\mathrm{s}}+\mathrm{t}_{\mathrm{o}}\right)^{2} \cdot\left(\rho_{\mathrm{h}}+\rho_{\mathrm{l}}\right)}
\end{aligned}
$$

ここで

$\mathrm{E}_{\mathrm{S}}:$ 鉄筋のヤング係数 $\left(\mathrm{N} / \mathrm{mm}^{2}\right)$

$\mathrm{t}_{\mathrm{o}}$ ：ねじり有効せい $(\mathrm{mm})<$ 図 12 参照 $>$

$\rho_{\mathrm{h}}:$ 式（18）による。

$$
\rho_{\mathrm{h}}=\frac{2 \mathrm{a}_{\mathrm{sh}}\left(\mathrm{C}_{1}+2 \mathrm{t}_{\mathrm{s}}+\mathrm{t}_{\mathrm{o}}\right)}{\left(\mathrm{C}_{1}+2 \mathrm{t}_{\mathrm{S}}\right) \cdot \mathrm{t}_{\mathrm{O}} \cdot \mathrm{p}}
$$

$\rho_{1}:$ 式（19）による。

$$
\rho_{1}=\frac{A_{1}}{\left(C_{1}+2 t_{S}\right) \cdot t_{0}}
$$

$\mathrm{A}_{1}$ : ねじり有効幅 $\left(=\mathrm{C} 1+2 \cdot \mathrm{t}_{\mathrm{s}}\right)$ 内の全配力筋断面積 $\left(\mathrm{mm}^{2}\right)$ $<$ 図 12 参照 $>$

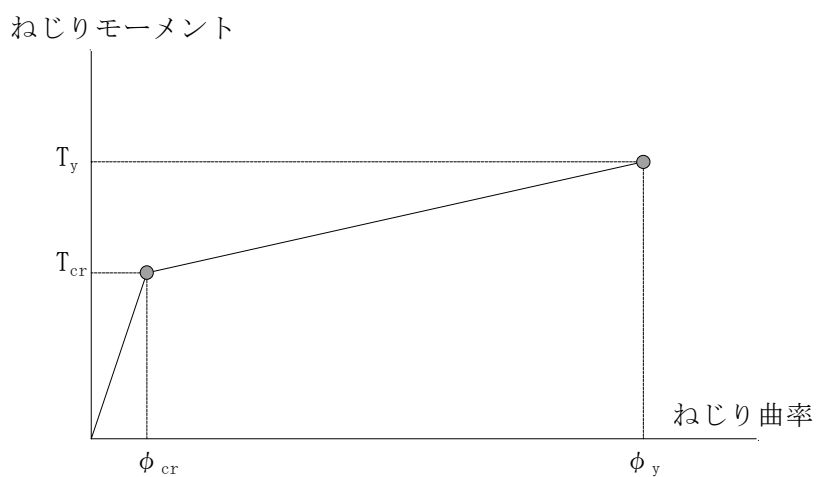

図 11 ねじりモーメントとねじり曲率の関係

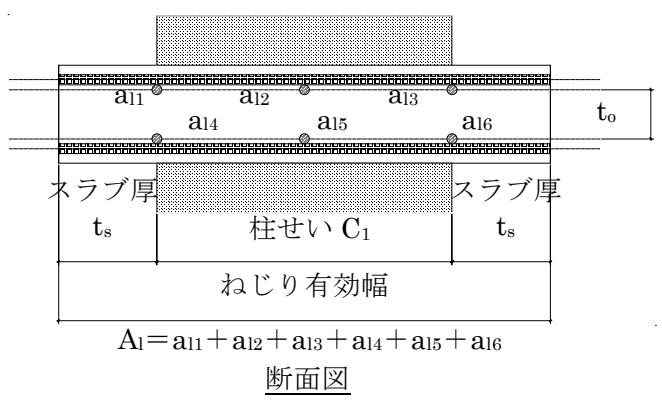

図 12 ねじり要素に関する諸定数

図 8 に示した $\mathrm{M}_{\mathrm{ct}}$ より求められるねじり曲率を積分して算出した ねじり回転角 $\theta_{\mathrm{t}}$ より, ねじり要素変形 $\delta_{\mathrm{t}}$ は式 $(20)$ により算出され る。

$$
\delta_{\mathrm{t}}=\theta_{\mathrm{t}} \cdot\left(0.5 \cdot \mathrm{C}_{1}+\mathrm{t}_{\mathrm{s}}\right)
$$

6）曲げ要素の変形 $\delta_{\mathrm{b}}$ とねじり要素の変形 $\delta_{\mathrm{t}}$ の適合

図 13 の変形適合位置において, 曲げ要素変形 $\delta_{\mathrm{b}}$ とねじり要素変 形 $\delta_{\mathrm{t}}$ の值が一致するまで，2)㸚じり要素のねじり有効長さおよび曲 げモーメント分布の仮定から 5)永じり要素の変形 $\delta \mathrm{t}$ の算出を繰り 返し計算する。

7）層間変形角 $\mathrm{R} の$ 算定

層間変形角 $\mathrm{R}$ は，式（21）により算出する。

$$
\mathrm{R}=\delta_{\mathrm{s}} / \mathrm{L}_{\mathrm{s}}+\delta_{\mathrm{c}} / \mathrm{L}_{\mathrm{c}}
$$


図 14 にスラブ先端の変形 $\delta \mathrm{s}$ 示す。 $\delta \mathrm{s}$ は式(22)によるものとす る。曲げ要素とスラブの先端要素の接合位置では変形, 曲率および 回転角は連続するとし, ねじれ要素とスラブの先端要素の接合位置 では変形は連続するが曲率および回転角は不連続とした。

$\delta_{\mathrm{S}}:$ スラブ先端の変形

$$
\delta_{\mathrm{s}}=\delta_{\mathrm{b}}+\theta_{\mathrm{b}} \cdot\left(\mathrm{L}_{\mathrm{s}}-0.5 \mathrm{C}_{1}-\mathrm{t}_{\mathrm{s}}\right)+\delta_{\text {top }}
$$

$\theta_{\mathrm{b}} \quad:$ 曲げ要素先端の回転角

曲げ要素の断面解析で算出した曲率を材軸長であるスラブ 厚に対して積分した回転角之柱前面（後面）せん断力と曲 げ要素のせん断弾性剛性より算出した回転角の和

$\delta_{\text {top }}$ 先端要素の曲げ変形 $<$ 式（23）による>

$$
\delta_{\text {top }}=\frac{\mathrm{Q}_{\mathrm{s}}\left(\mathrm{L}_{\mathrm{S}}-0.5 \mathrm{C}_{1}-\mathrm{t}_{\mathrm{S}}\right)^{3}}{3 \mathrm{E}_{\mathrm{c}} \mathrm{I}_{\text {top }}}
$$

$I_{\text {top }}$ : スラブ全幅有効としたスラブの断面 2 次モーメント

$\mathrm{E}_{\mathrm{c}} \quad$ : スラブのコンクリートのヤング係数

$\mathrm{L}_{\mathrm{S}} \quad$ : 柱中心からスラブ反曲点位置までの距離

$\delta_{\mathrm{c}} \quad:$ 柱の曲げおよびせん断変形の和

$\mathrm{L}_{\mathrm{c}} \quad$ : スラブ中心から柱支持位置までの距離

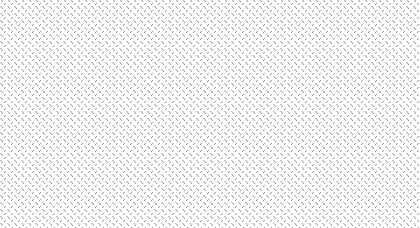

A-A 断面位置全体図
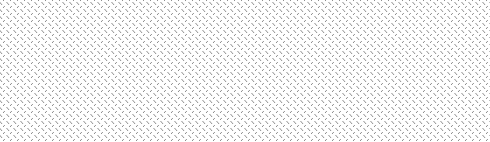

$\mathrm{A}-\mathrm{A}$ 断面

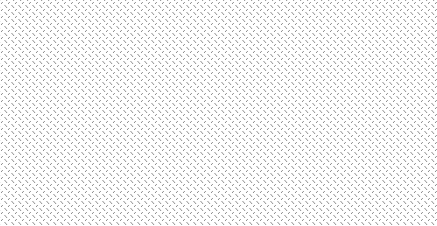

B-B 断面位置全体図

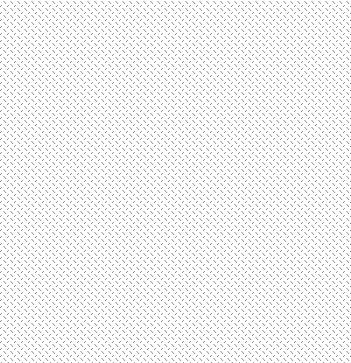

B-B 断面 立断面図

図 13 曲げ要素とねじり要素の変形の適合

\section{3. マクロモデルによる計算值と実験値の比較 \\ (1) 対象とする試験体概要}

マクロモデルによる検討を行う試験体一覧を表 1 に示す。各試験 体に関する試験体の詳細および実験結果に関しては, 各参考文献に よるものとする。検討する試験体は筆者らが実験を行った壁柱とフ ラットプレートから構成される部分試験体 ${ }^{22)}$ 25) に加えて, 狩野ら による正方形の柱とフラットプレートから構成される試験体 ${ }^{3), 26)}$ も対象とした。

\begin{tabular}{|c|c|c|c|c|c|c|c|c|}
\hline \multirow[b]{2}{*}{$\begin{array}{l}\text { 試験 } \\
\text { 体名 }\end{array}$} & \multicolumn{3}{|c|}{ 柱 } & \multicolumn{3}{|c|}{ スラブ } & \multirow{2}{*}{$\begin{array}{c}\text { 直交壁※4 } \\
\text { の } \\
\text { 有無 }\end{array}$} & \multirow[b]{2}{*}{$\begin{array}{l}\text { 文献 } \\
\text { 番号 }\end{array}$} \\
\hline & $\begin{array}{l}\text { せい } \\
\mathrm{mm}\end{array}$ & $\begin{array}{l}\text { 幅 } \\
\mathrm{mm}\end{array}$ & タイプ※ & $\begin{array}{c}\text { 厚さ } \\
\text { mm }\end{array}$ & $\begin{array}{c}\text { 長さ※2 } \\
\mathrm{mm}\end{array}$ & $\begin{array}{c}\text { 幅※3 } \\
\text { mm }\end{array}$ & & \\
\hline$\overline{\mathrm{CN} 1}$ & 500 & 200 & 内柱 & 85 & 2200 & 2200 & \begin{tabular}{l|l} 
無 \\
\end{tabular} & 22 \\
\hline CW1 & 500 & 200 & 内柱 & 85 & 2200 & 2200 & 有 & 22 \\
\hline SW1 & 500 & 200 & 側柱 & 85 & 2200 & 2200 & 有 & 22 \\
\hline CW2 & 500 & 200 & 外柱 & 85 & 2200 & 2200 & 有 & 23 \\
\hline SW2 & 500 & 200 & $\begin{array}{l}\text { 隅柱 } \\
\end{array}$ & 85 & 2200 & 2200 & 有 & 23 \\
\hline No. 1 & 600 & 200 & 内柱 & 100 & 2100 & 2700 & 有 & 24 \\
\hline No. 2 & 600 & 200 & 内柱 & 100 & 2100 & 2700 & 有 & 24 \\
\hline No. 3 & 600 & 200 & 内柱 & 100 & 2100 & 2700 & 有 & 24 \\
\hline $\mathrm{SH}$ & 500 & 200 & 内柱 & 85 & 2400 & 2400 & $\begin{array}{l}\text { 無 } \\
\end{array}$ & 25 \\
\hline SY & 200 & 500 & 側柱 & 85 & 2000 & 2400 & \begin{tabular}{l|} 
無 \\
\end{tabular} & 25 \\
\hline $\mathrm{CH}$ & 150 & 500 & 内柱 & 85 & 2400 & 3800 & \begin{tabular}{l|} 
無 \\
\end{tabular} & 25 \\
\hline $\mathrm{H}-7$ & 200 & 200 & 内柱 & 100 & 2400 & 2400 & $\begin{array}{l}\text { 無 } \\
\end{array}$ & 3 \\
\hline No. 7 & 250 & 250 & 外柱 & 100 & 2500 & 2900 & $\begin{array}{l}\text { 無 } \\
\end{array}$ & 26 \\
\hline
\end{tabular}

表 1 試験体一覧

※1 柱のタイプは水平荷重 方向と平面位置から 右図と示す。

$※ 2$ 水平荷重に対するスラブ

反曲点位置間距離 $※ 3$ 水平荷重に対して直交 方向のスラブ長さ $※ 4$ 水平荷重に対して直交 方向する柱に隣接する壁

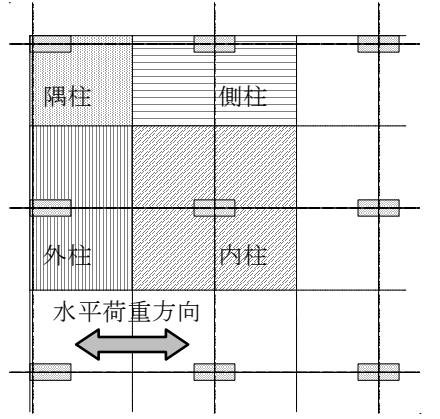

マクロモデル計算時における曲げ要素の曲げ有効幅 $\mathrm{h} b$ は, 各柱夕 イプに対する直交壁の影響を考慮して，以下の值とした。

1）柱タイプが内柱または側柱の場合
$\mathrm{h}_{\mathrm{b}}=\mathrm{t}_{\mathrm{s}}$
＜曲げ要素ひび割れ前＞
$\mathrm{h}_{\mathrm{b}}=2.5 \mathrm{t}_{\mathrm{s}}$
<曲げ要素ひび割れ後 $>$

2）直交壁を有する外柱または隅柱タイプ
$\mathrm{h}_{\mathrm{b}}=\mathrm{t}_{\mathrm{s}}$
<曲げ要素ひび割れ前 $>$
$\mathrm{h}_{\mathrm{b}}=1.5 \mathrm{t}_{\mathrm{s}}$
<曲げ要素ひび割れ後 $>$

3）直交壁の無い外柱または隅柱タイプ

$$
\begin{array}{ll}
\mathrm{h}_{\mathrm{b}}=\mathrm{t}_{\mathrm{s}} & <\text { 曲げ要素ひび割れ前 }> \\
\mathrm{h}_{\mathrm{b}}=\mathrm{t}_{\mathrm{s}} & <\text { 曲げ要素ひび割れ後 }>
\end{array}
$$

\section{(2) 柱せん断力と層間変形角の関係の比較}

上記の実験結果の柱せん断力と層間変形角の関係における包絡曲 線の実験值と計算值の比較を 15 に示寸。図中にはスラブ主筋の降 伏開始時も合わせて表記している。各試験体ともにマクロモデルに よる計算值は実験值を良く表わしているが, 試験体 No. 3 の計算値は, 
実験值のスラブ主筋降伏以降における耐力上昇を過小評価している。 これは, 試験体 No. 3 では試験体 No. 2 に変形性能を向上させる補強 筋を付加しており, 試験体 No. 2 において層間変形角 20/1000 時に発 生した柱近傍の主筋降伏以降のパンチング破壊を防止とともに補強 筋自身が耐力上昇に寄与したためと考えられる。また, 試験体 $\mathrm{CH}$ のスラブ主筋の降伏開始時の層間変形角計算値は実験值よりやや小 さい。
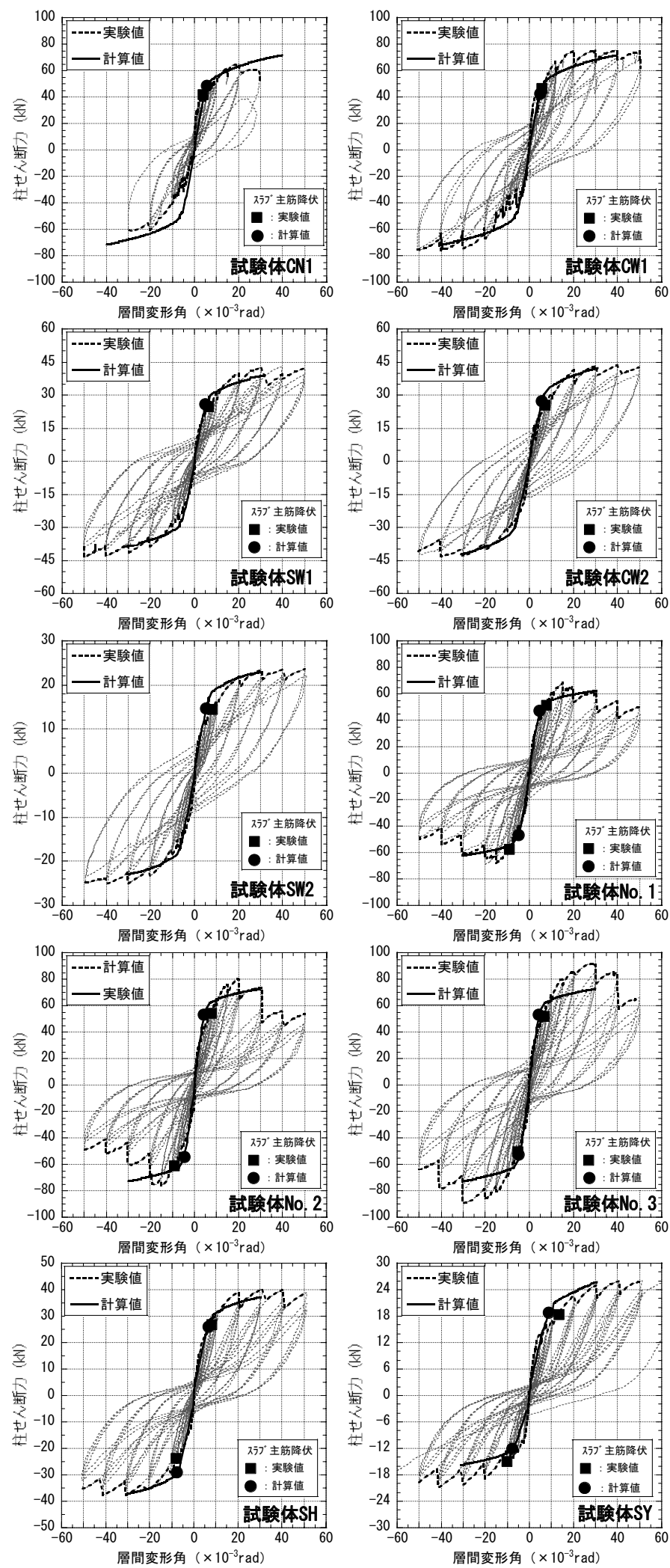
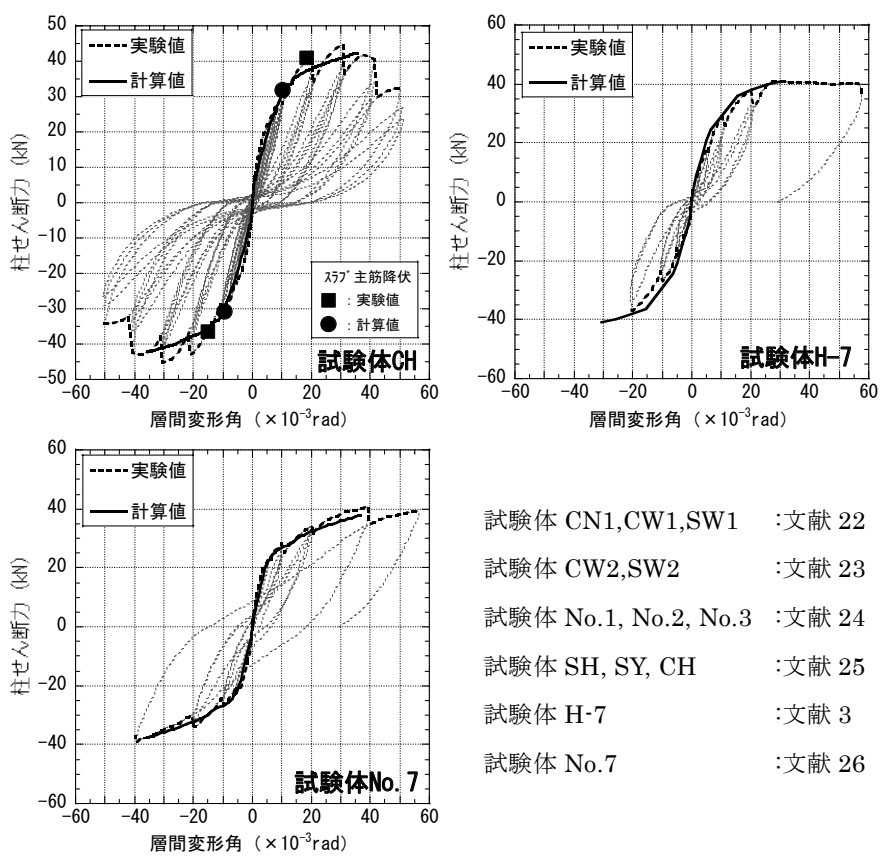

試験体 CN1,CW1,SW1：文献 22 試験体 CW2,SW2 :文献 23 試験体 No.1, No.2, No.3 :文献 24 試験体 $\mathrm{SH}, \mathrm{SY}, \mathrm{CH}$ : 文献 25 試験体 $\mathrm{H}-7$ : :文献 3 試験体 No.7 :文献 26

図 15 柱せん断カと層間変形角の実験值と計算値との比較

表 2 に各試験体における初期剛性と最大耐力時剛性に関する計算 值に対する実験值の比率（実験地/計算值）を示す。ここで，初期剛 性は層間変形角 2.5/1000 rad 時の割線剛性, 最大耐力時剛性は層間 変形角 10/1000 rad 時の割線剛性を示す。初期剛性に関する計算値に 対する実験值の比率の平均は, 正加力時 1.24 負加力時 1.19 , 最大 耐力時剛性に関する計算值に対する実験值の比率の平均は, 正加力 時 0.99 負加力時 0.96 で, 比較的良く一致している。

\section{表 2 剛性に関する計算値に対する実験值の比率}

\begin{tabular}{l|r|r|r|r}
\hline & \multicolumn{2}{|c|}{ 初期剛性 } & \multicolumn{2}{c}{ 最大耐力時剛性 } \\
\cline { 2 - 5 } & 正加力時 & 負加力時 & 正加力時 & 負加力時 \\
\hline CN1 & 1.58 & 0.62 & 1.01 & 0.74 \\
\hline CW1 & 1.61 & 1.20 & 1.12 & 0.73 \\
\hline SW1 & 1.17 & 1.10 & 0.97 & 0.94 \\
\hline CW2 & 1.27 & 1.43 & 0.90 & 0.93 \\
\hline SW2 & 1.18 & 1.40 & 0.85 & 0.96 \\
\hline No.1 & 1.06 & 1.06 & 1.10 & 1.10 \\
\hline No.2 & 1.01 & 1.01 & 0.99 & 0.97 \\
\hline No. 3 & 0.98 & 1.07 & 1.06 & 1.08 \\
\hline SH & 1.34 & 1.12 & 0.99 & 0.91 \\
\hline SY & 1.55 & 1.90 & 0.88 & 1.15 \\
\hline CH & 1.22 & 1.26 & 0.99 & 1.01 \\
\hline H-7 & 0.91 & 1.01 & 0.99 & 0.93 \\
\hline No.7 & 1.28 & 1.28 & 1.04 & 1.00 \\
\hline \hline 平均值 & 1.24 & 1.19 & 0.99 & 0.96 \\
\hline 最大 & 1.61 & 1.90 & 1.12 & 1.15 \\
\hline 最小 & 0.91 & 0.62 & 0.85 & 0.73 \\
\hline 標準偏差 & 0.23 & 0.30 & 0.08 & 0.12 \\
\hline & & & &
\end{tabular}

\section{(3) スラブ主筋の応力分布の比較}

柱隅角部から加力方向と直交する位置における正加力時のスラブ 主筋の応力分布の比較を図 16 に示す。応力分布はほぼ最大耐力時 と考えられる層間変形角 10/1000 rad 時の值とする。スラブ主筋実験 值はスラブ主筋に貼付したひずみゲージのひずみから算出した。マ クロモデルによる計算值は, 曲げ要素位置では曲げ要素の断面解析 
において算出される值, ねじり要素位置では算出される単位長さ当 たりのねじりモーメントに対する単位長さあたりの引張側のスラブ 主筋の断面積と曲げモーメント応力中心間距離 $7 / 8 \mathrm{~d}$ (d は有効せい) から計算した值とした。ここで, 単位長さ当たりの引張側のスラブ 主筋の断面積は, 加力方向と平行な引張側のスラブ筋の断面積とピ ッチから算出した。また, 主筋の応力とひずみの関係式にひずみ硬 化を考慮したおよび島ら 20) による式を用いるため, 鉄筋の応力が 降伏強度を超えている場合がある。

試験体 SY, CH に関しては, 全体的に計算值は実験值をやや過大評 価している。また，マクロモデルによる計算ではねじり要素の曲げ モーメント分布を線形分布としているため, 応力分布の計算值は線 形分布となっているが, 曲げ要素に近いねじり要素の計算値は実験 值を過大評価している。しかし，応力がゼロになる位置などおおむ ね計算値は実験值を良く表している。
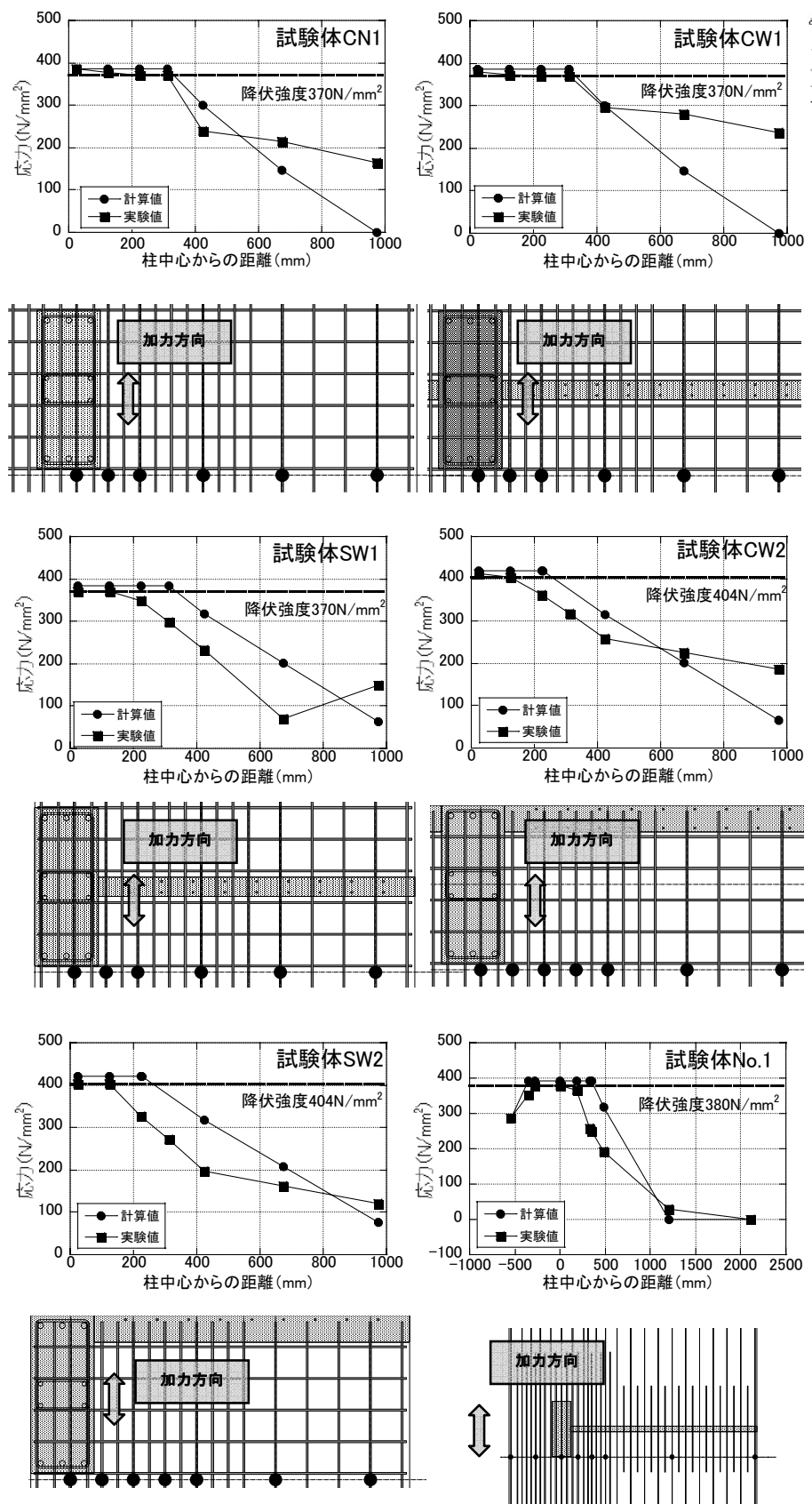
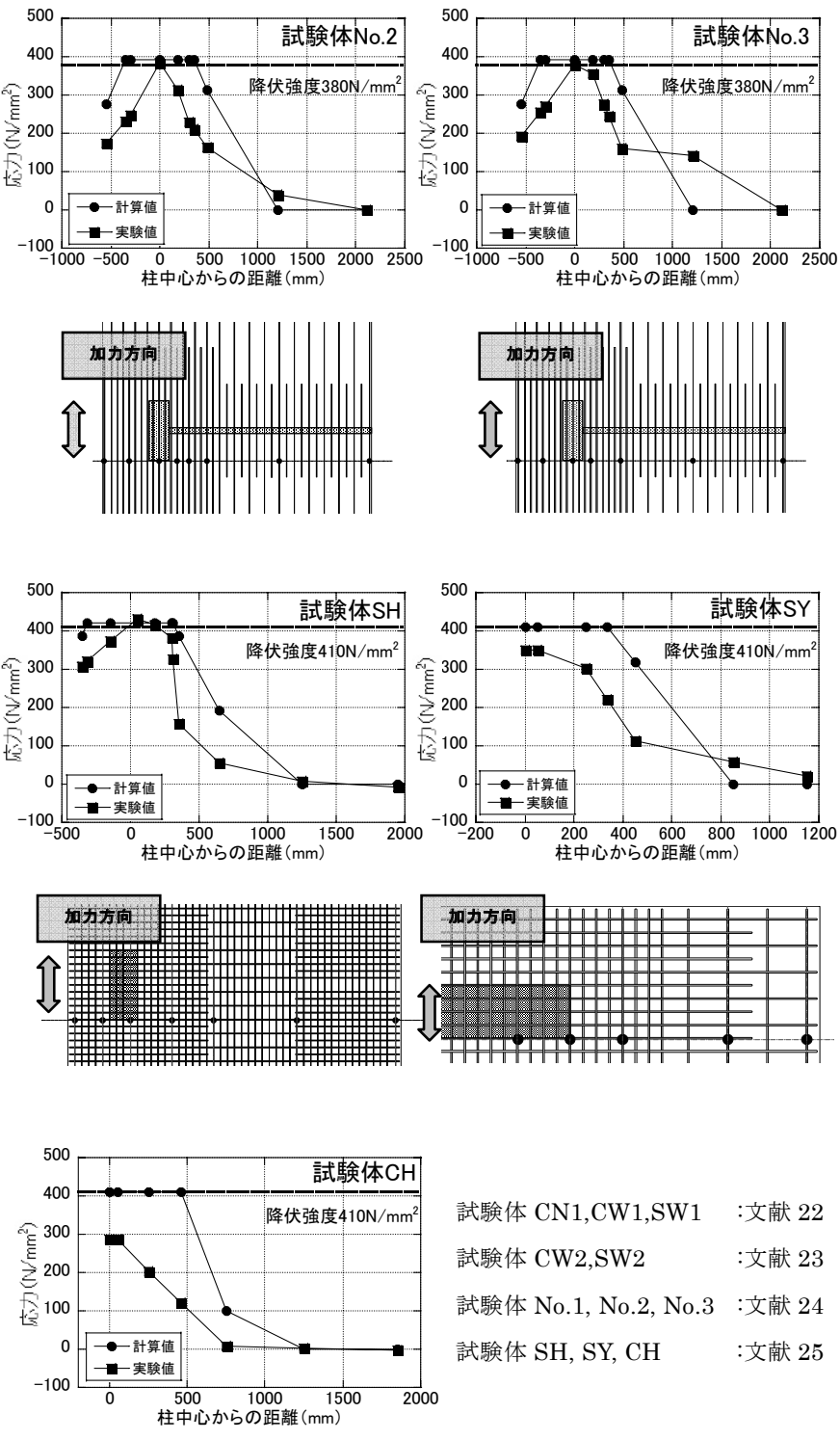

試験体 CN1,CW1,SW1 :文献 22 試験体 CW2,SW2 :文献 23 試験体 No.1, No.2, No.3 :文献 24 試験体 $\mathrm{SH}, \mathrm{SY}, \mathrm{CH}$ :文献 25

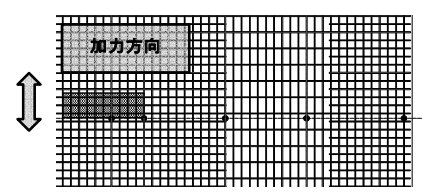

図 16 スラブ主筋の応力分布の実験值と計算值との比較

（4）曲げ要素内のスラブ主筋の定着部における応力の比較 試験体 SY の試験体形状図およびスラブ配筋図を図 17 , 対象と するマクロモデルにおける曲げ要素内にあたるスラブ主筋のひずみ 計測位置を図 18 に示す。

各サイクルのピーク時におけるスラブ主筋のひずみの変化を図 1 9 に示す。スラブ柱面において主筋のひずみが降伏ひずみに達して いない層間変形角 $10 \times 10^{-3}$ までは，上端筋，下端筋ともに定着部の ひずみ計測位置では主筋のひずみがほとんど発生していない。しか し，スラブ柱面において主筋のひずみが降伏ひずみを超えると，上 端筋，下端筋ともに定着部のひずみ計測位置では主筋のひずみが増 加する。 
層間変形角 $7.5,10.0,20.0 \times 10^{-3}$ 時における曲げ要素のスラブ主 筋の定着部における応力分布計算值を図 20 に示す。スラブ主筋の 応力分布は主筋の抜け出し量 $\mathrm{S}$ の算出時に計算される鉄筋のひずみ と鉄筋の引張試験から得られた応力ひずみ関係より算出した。図 2 0 には図 16 で示したひずみ計測位置でのスラブ主筋における忍力 の実験值も合わせて示す。図 20 において, スラブ柱面から鉄筋応 力が 0 まで長さを定着長とすると, 計算值では層間変形角 $20.0 \times$ $10^{-3}$ まで定着長は定着部のひず夕計測位置まで達していない。スラ ブ柱面において主筋が降伏するまでは，定着部のひずみ計測位置ま では定着長が達していない実験結果と一致する。しかし，スラブ柱 面で主筋が降伏してからの変形時では定着部のひずみ計測位置にお いてスラブ主筋の応力実験值は増加しており, 計算值と一致してい ない。定着部を中心にスラブ筋の軸方向の応力分布や端部等からの スラブ筋の抜け出し量の定量的な評価に関しては今後の検討課題と する。

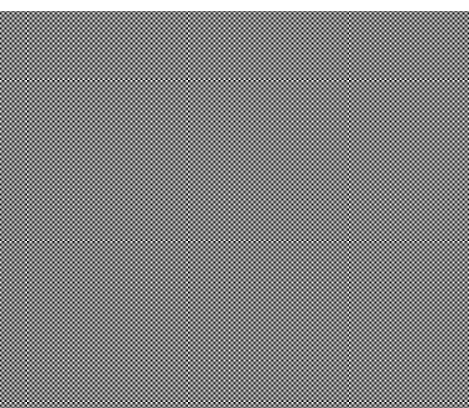

平面図

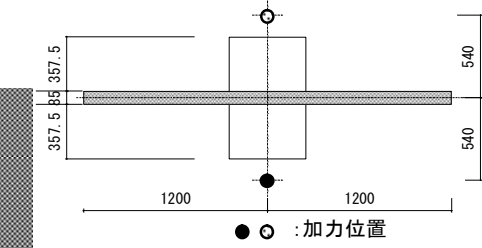

A-A 断面図

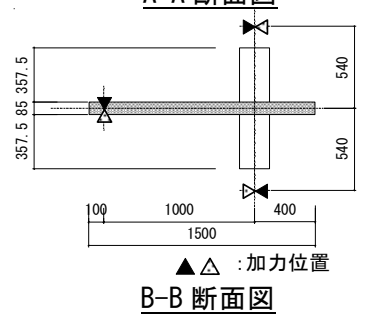

B-B 断面図

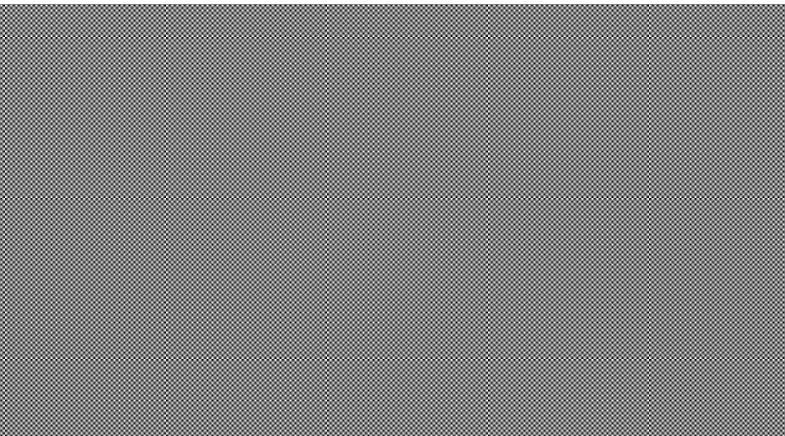

上端筋

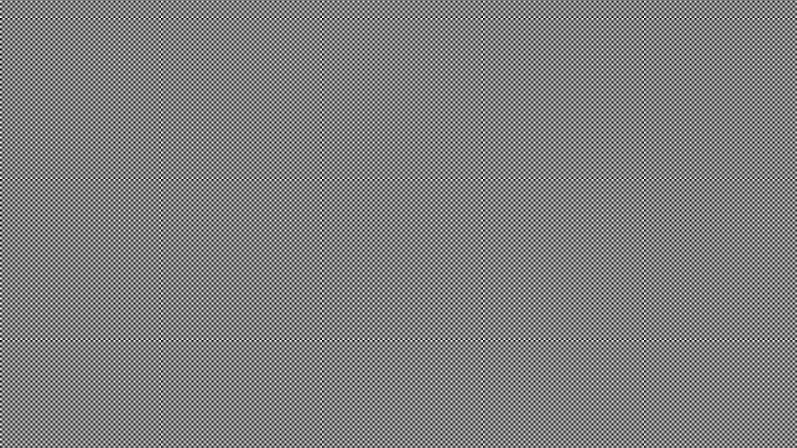

下端筋
図 17 試験体 SY 形状図およびスラブ配筋図

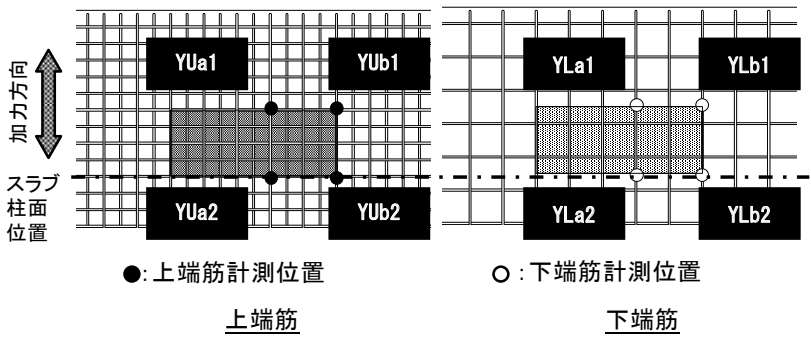

図 18 試験体 SY スラブ主筋のひずみ計測位置図
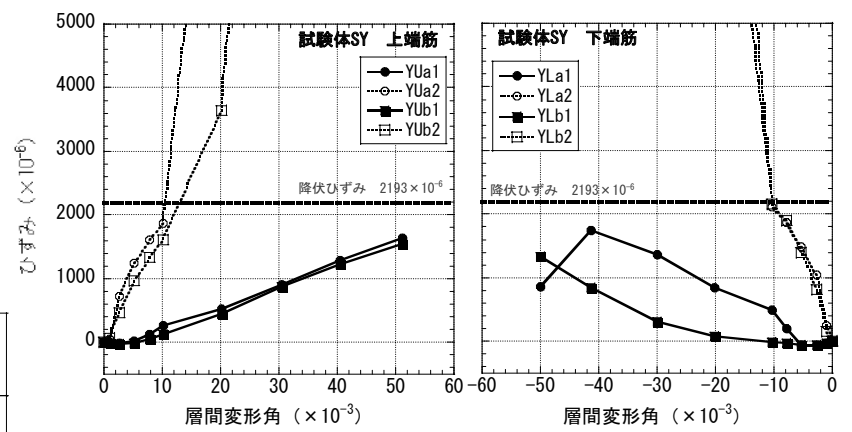

図 19 試験体 SY 各サイクルピーク時のスラブ主筋のひずみ
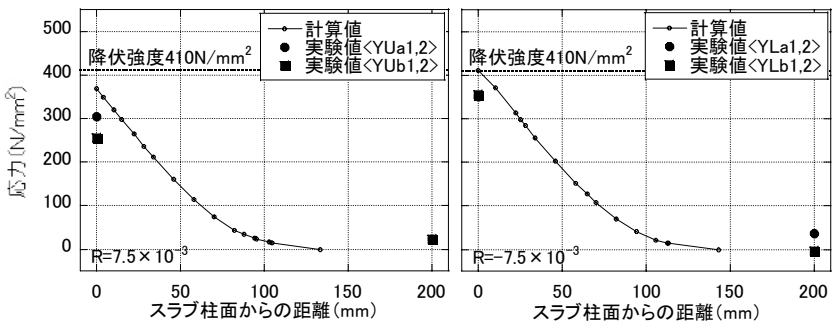

層間変形角 $7.5 \times 10^{-3}$
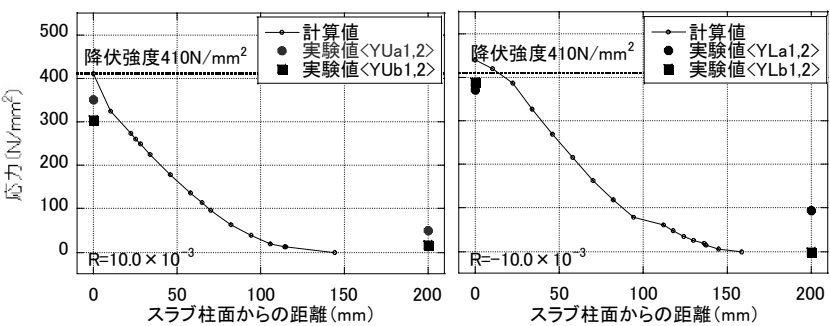

層間変形角 $10.0 \times 10^{-3}$
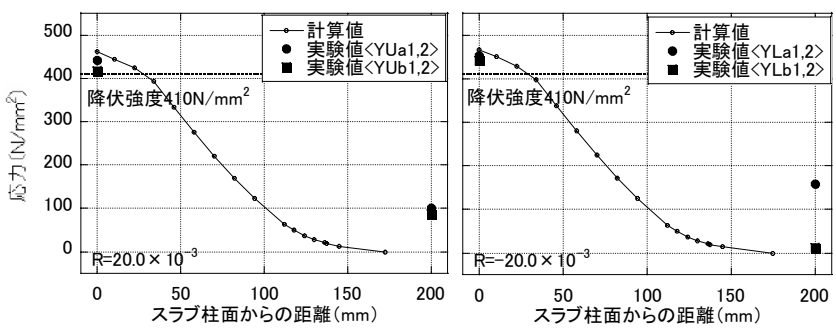

層間変形角 $20.0 \times 10^{-3}$

図 20 スラブ主筋の定着部における応力分布計算值 


\section{4. おわりに}

フラットプレート構造の地震時を想定した水平荷重を受けた場合 の耐力および岡性の算定に関して, 柱とスラブの応力伝達を適切に 表現可能かつスラブの非線形性を考慮したマクロモデルによる算定 方法を提案し, 柱とフラットプレートから構成される部分試験体の 実験結果と比較検討した。得られた結果は以下の通りである。

（1）柱せん断力と層間変形角の関係における包絡曲線に関して, マクロモデルによる計算值は実験值を良く表わしている。

(2) 層間変形角 10/1000 rad 時における柱隅角部から加力方向と直 交寸る位置における正加力時のスラブ主筋の応力分布に関して, マ クロモデルによる計算值は実験值を良く表わしている。

（３）ママクロモデルにおける曲げ要素内にあたるスラブ主筋の定着 部における応力に関して, マクロモデルによる計算值と実験值を比 較した。スラブ柱面において鉄筋の応力が降伏応力に達するまでは, 計算值は実験值と一致するが, 鉄筋の応力が降伏応力に達した後は, 計算值は実験值と一致しない。スラブ筋の軸方向の応力分布や抜け 出し量など今後の検討課題とする。

以上より，フラットプレート構造の地震時を想定した水平荷重を 受けた場合の耐力および剛性の算定方法として, 提案したマクロモ デルによる算定方法は, 柱とスラブの応力伝達を適切に表現しなが ら，スラブの非線形性を考慮できる方法であることを示した。スラ ブ筋のスラブ内および定着部における応力分布や抜け出し量の算定 に関しては今後さらに検討していく必要がある。

\section{謝辞}

本論文は，平成 10 年度新エネルギー産業技術総合開発機構 （NEDO）から委託を受けた研究の成果の一部を用いている。尚, 本研究にあたって, 渡邊史夫京都大学名誉教授, 西山峰広京都大学 教授よりご指導を頂きました。ここに謝意を表します。

\section{参考文献}

1）中村幸太郎，清水美木夫，林信之：コア集約型新架構法による超高層集 合住宅の施工, コンクリート工学, Vol. 40, No. 11, pp. 42-48, 2002

2）山本正幸, 室屋哲也, 太田義弘, 大津勝也 : 超高層免震壁柱フラットプ レート構造の開発と実施，コンクリート工学，Vol. 41， No. 7, pp. 47-53, 2003

3）狩野芳一, 吉崎征二 : フラットプレート構造の柱-スラブ接合部に関する 研究，その 1 水平荷重を受ける接合部の実験，日本建築学会論文報告集， No. 288 , pp. $39-47,1980.2$

4）狩野芳一, 吉崎征二 : フラットプレート構造の柱-スラブ接合部に関する 研究, その 2 鉛直荷重と水平荷重を受ける接合部の実験, 日本建築学会論 文報告集，No. $292 ，$ pp. 31-39，1980.6

5）狩野芳一, 吉崎征二 : フラットプレート構造の柱-スラブ接合部に関する 研究, その 3 接合部の礼じり実験, 日本建築学会論文報告集, No. 300 , pp. 41-48, 1981. 2

6）狩野芳一, 吉崎征二 : フラットプレート構造の柱-スラブ接合部に関する 研究, その 4 終局せん断強度算定法とその確証実験, 日本建築学会論文報 告集, No. 309, pp. 29-40, 1981.11

7）日本建築学会 : 鉄筋コンクリート構造計算規準・同解説，pp. 102-114, 2010. 2

8）高田香織, 津田和明, 江戸宏彰：フラットプレート構造の高層建物への 適用に関寸る研究 その 1 フラットプレート・柱接合部の性能確認実験, 日本建築学会大会学術講演梗概集, C-2, 構造IV, pp. 419-420, 1997.7

9）津田和明, 高田香織, 江戸宏彰 : フラットプレート構造の高層建物への 適用に関する研究 その 2 フラットプレート・柱接合部の性能確認実験,
日本建築学会大会学術講演梗概集， C-2，構造IV, pp. 421-422, 1997.7

10）高田香織, 津田和明, 佐野剛志, 江戸宏彰：フラットプレート構造の高 層建物一の適用に関寸る研究 その 3 復元力特性の評価手法, 日本建築学 会大会学術講演梗概集, C-2, 構造IV, pp. 685-686, 1998.7

11）佐野剛志，津田和明，高田香織，江戸宏彰：フラットプレート構造の高 層建物一の適用に関寸る研究 その 4 高層建物の試設計, 日本建築学会大 会学術講演梗概集，C-2，構造IV, pp. 687-688, 1998.7

12）高田香織, 津田和明, 江戸宏彰 : フラットプレート構造の高層建物への 適用に関する研究 ，日本コンクリート工学協会 年次論文報告集, Vo. 21, No. 3, pp. 697-702, 1999

13) Y. H. Luo, A. J. Durrani : Equivalent Beam Model for Flat-Slab Buildings Part I, Interior Connections, ACI Structural Journal, Vol.92, No. 1, pp. 115-124, 1995

14) Y. H. Luo, A. J. Durrani : Equivalent Beam Model for Flat-Slab Buildings PartII , Exterior Connections, ACI Structural Journal, Vo1.92, No. 2, pp. 250-257, 1995

15) Hawkins : Lateral Load Design Considerations for Flat-Plate Structures, CSCE-ASCE-ACI-CEB International Symposium University Waterloo, pp. 581-614, 1979.8

16) Fred Allen, Peter Darva11, : Lateral Load Equivalent Frame, ACI Journal, Vol. 74, No. 7, pp. 294-299, 1977

17) 深津 尚人，木村 政義，佐多 将樹，清水 啓介，田口孝，神谷 隆，市之瀬 敏勝, フラットプレート構造の水平荷重下における柱-スラブ 接合部のせん断補強筋の評価手法の提案, その 1 評価方法, 日本建築学会 大会学術講演梗概集, C-2, 構造 IV, pp. 667-668, 2010. 7

18) 清水 啓介，木村 政義，佐多 将樹，深津 尚人，田口孝，神谷 隆，市之瀬 敏勝: フラットプレート構造の水平荷重下における柱-スラブ 接合部のせん断補強筋の評価手法の提案, その 2 計算結果・検討, 日本 建築学会大会学術講演梗概集, C-2, 構造 IV, pp. 669-670, 2010. 7

19) 財団法人国土開発技術研究センター: 建設省総合開発プロジェクト鉄筋コ ンクリート造建築物の超軽量・超高層化技術の開発 平成 4 年度 New RC 研究開発概要報告書, pp. 3-2-79-88, 1993.3

20)島弘，周礼良，岡村甫：異形鉄筋の鉄筋降伏後における付着性状，土木学 会論文集，Vol.378，V-6，pp. 213-220,1987.2

21) 島弘, 周礼良, 岡村甫 : マッシブなコンクリートに埋め込まれた異形鉄筋 の付着応力ーすべりーひずみ関係，土木学会論文集，Vol. 378，V-6， pp. 165-174, 1987.2

22) 太田義弘, 岡本晴彦, 山本正幸, 室谷哲也 : 壁柱・フラットプレート架構 の地震荷重下における履歴復元力特性, コンクリート年次論文報告集, Vol. 20, No. 3, pp. 907-912, 1998. 7

23) 太田義弘, 岡本晴彦, 山本正幸, 室谷哲也, 関光雄 : 壁柱・フラットプレ 一ト架構の地震荷重下における層せん断力一層間変形角の包絡曲線に関す る研究, 日本建築学会大会学術講演梗概集, C-2, 構造IV, pp. 661-662, 1999.9

24）太田義弘, 岡本晴彦, 山本正幸, 室谷哲也, 太田博章, 楠原文雄 : 壁柱 · フラットプレート架構の靭性性能に関する研究, 日本建築学会大会学術講 演梗概集， C-2，構造IV，pp. 99-100，2002.8

25）太田義弘, 岡本晴彦, 山本正幸, 太田博章 : 水平荷重を受けるフラット プレート架構の力学的挙動に関寸る研究, コンクリート年次論文報告集, Vol.24, No. 2, pp. 565-570, 2002.7

26）諏訪寛，西田哲也，吉崎征二，狩野芳一 : 高強度コンクリートフラット プレート構造の開発 (1) 側柱一スラブ接合部の実験概要，日本建築学会 大会学術講演梗概集， C-2，構造IV，pp. 887-888， 1993.9 


\section{Yoshihiro OHTA* ${ }^{*}$, Taku KAWAI** and Hiroaki OHTA*** \\ * Vice Senior Manager, Technology Department, Takenaka Corporation, M. Eng. * Group Leader, Building Design Department, Takenaka Corporation, M. Eng. \\ *** Manager, Building Design Department, Takenaka Corporation, M. Eng.}

This paper describes a model for the stiffness and the strength of flat-plate structures under the lateral loads. The performance of slab to column connections transferring moments and shears in the lateral loads can be realistically predicted by this model.

The model developed by the authors is based on Stub Beam Model by N.Hawkins et al. and used accepted reinforced concrete principals as the model developed by N.Hawkins et al.. In the model by N.Hawkins et al., the column is connected to the flexural elements and torsional elements. The deformation of the flexural element and it of torsional element to each moment by lateral loads are inter-related by requiring that they are match for a point.

But the model developed by N.Hawkins et al. has weak points as followed.

1. The model developed by N.Hawkins et al. predicts the relations of moments and rotations nearby slab to column connections.

2. The developments of deformations at the slab to the direction perpendicular to lateral loads measured in tests can't be predicted by the model developed by N.Hawkins et al..

The model developed by the authors improves these weak points.

The results of tests for 10 slab-interior column specimens and 3 slab-exterior specimens under lateral loads are simulated by the model developed by the authors.

As a results, the following things are shown.

1. The predicted shear force at column - story drift envelopes by this model agree with the measured ones.

2. The predicted distributions for stresses of the reinforced steels at the critical section of slab by this model agree with the measured ones.

3. After the reinforced steels at the critical section of slab are yielded, the predicted and measured values for the reinforced steels stresses of slab in the anchor aren't in good agreement. This is investigated in future. 